in proper serological reactions (ono of which appears to be the indirect hæmagglutination test). Further work will show whether this hypothetical ' $C$-antigen' is common to all Gram-negative bacteria and of what importance it may be. We have found it up to the presont in: S. typhi, S. paratyphi B, S. chester, $S$. typhimurium, S. cholerae suis and Shigella sonnei. Thanks are expressod to Prof. O. Westphal and to Dr. O. Lüderitz (Dr. A. Wander Forschungsinstitut, Freiburg) for helpful discussions and support, and to Miss L. Thoile for her excollont technical help.

H. Bronhage

Department of Pathology and Bacteriology, Cantonal Goneral Hospital, Lucerne, Switzerland.

' Walker, J., Biochem. J., 34, 825 (1940).

Mland, C. N., Laneet, i, 277 (1953).

3 Toda, Y., Ann. Tuberc. (Tenri), '7, 1 (1956).

4 Neter, E., Westphal, O., Lucderitz, O., and Gorzynskı, E. A., Ann. $N . Y$. Acad. Sci., BB 141 (1956). Neter, E., Gorzynski, 19. A. Gino, R. M. Westphal, O., and Iuederit\%, O., Canad. J. Microbiol., 2, 232 (1956).

s Brodhage, H., Z, IIyg., 148, 94 (1961).

- Weinbach, R., Schweiz. Z. Path. Bact, 21, 1043 (1959).

= Gillissen, G., Z, Hyg., 148, 105 (1961).

\section{Utilization of Inorganic Sulphate labelled with Sulphur-35 by Torulopsis utilis}

It has been established ${ }^{1}$ that inorganic and organic sulphurs are utilized by growing yeast. Moro recently ${ }^{2}$ the conditions for the ahsorption of sulphur-35 by $S$. cerevisiae cells were examined and the necessity of nitrogen and glucose for the utilization of sulphur was demonstrated.

We have in the present exporiment examinod the utilization of sulphur-35 by T. utilis cells which were grown in inorganic salt medium enriched with yeast extract. From this the cells were eentrifuged at $0^{\circ} \mathrm{C}$., washed with ice-cold water and suspended in sterile water. Aliquots from this suspension were added to tho following modia (without yeast extract): (a) complete medium without nitrogen; (b) complete medium without sulphur.

Incubation was then carried out aerobically at $25 \pm 1^{\circ} \mathrm{C}$. for $24 \mathrm{hr}$. Then the colls woro centrifuged. and washed with ice-cold water and three suspensions were obtained. Aliquots from each one were added to the following media: (a) without nitrogen and glucose; (b) with nitrogen and without glucose; (c) without nitrogen and with glucose; (d) with nitrogen and glucose.

An amount of $\mathrm{K}_{2}{ }^{35} \mathrm{SO}_{4}$ was added to each medium in order to trace the utilization of sulphur by the cells during absorption periods of 60,120 and 180 min. The cells were then washed at $0^{\circ} \mathrm{C}$., aliquots from the washings being usod for determining tho radioactivity absorbed.

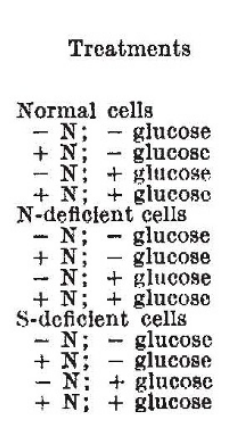

Table 1

\begin{tabular}{rcc}
\multicolumn{3}{c}{ Time of incubation } \\
60 & 120 & $\begin{array}{c}\text { (min.) } \\
180\end{array}$ \\
(c.p.m./gm. dry matter) \\
90 & 120 & 157 \\
104 & 194 & 282 \\
78 & 194 & 280 \\
200 & 244 & 294 \\
84 & 129 & 139 \\
138 & 212 & 216 \\
38 & 144 & 186 \\
169 & 185 & 195 \\
61 & & \\
119 & 98 & 145 \\
89 & 165 & 171 \\
150 & 185 & 243 \\
& & 255
\end{tabular}

If the radioactivity of $T$. utilis colls which were grown and allowed to absorb sulphur in complete media during $180 \mathrm{~min}$. is taken as 100 (Tablo $\mathrm{l}$ ), the following conclusions can bo drawn:

(1) Glucose and nitrogen are necessary for the utilization of sulphur-35 because:

(a) Colls that wero grown in complete medium when allowed to absorb sulphur-35 in modium without nitrogen and glucose showed only 53.4 per cent of absorption.

(b) When theso colls were allowed to absorb sulphur-35 in presence of nitrogen or glucose, they showed respectively $95 \cdot 9$ and $95 \cdot 2$ per cent absorption.

(c) Nitrogen-dofieient colls when allowed to absorb sulphur-35 in medium without nitrogen and glucose showed only 47.9 per cent absorption; when nitrogen or glucose or both wore present, however, the absorption was raised respectively to $73.4,63.4$ and 65.9 per eent. (d) Sulphur-deficient cells which were allowed to absorb sulphur-35 in medium without nitrogen or glucoso showod only $49 \cdot 3$ per cont of absorption. On the othor hand, when nitrogen or glucose or both were present, the absorption was raisod respectively to $58 \cdot 1,82 \cdot 3$ and $85 \cdot 7$ per cent.

(2) Nevertheless, nitrogen is not probably nooessary for absorption: sulphur-doficiont cells when allowed to absorb sulphur-35 in medium with nitrogen or in medium without nitrogen showed in both cases practically the same absorption: respectively $85 \cdot 7$ and $82 \cdot 3$ per cent. This is probably because in sulphur-doficient colls tho nitrogon contont is increased and thus the sulphur-containing compounds may be formed without any exogenous source of nitrogen ${ }^{3}$.

(3) The utilization of glucose by $T$. utilis colls absorbing sulphur-35 shows that probably the mechanism of sulphur absorption is an active one.

$$
\text { Oтто J. CRocomo }
$$

Department of Biological Chemistry, Louis Neptune Menard

Department of Agricultural Chemistry, Escola Superior de Agricultura Luiz de Queiroz, Universidado do São Paulo, Piracicaba, Brazil.

1 Schulz, A. S., and MeManus, D. K., Arch. Biochem., 25, 401 (1950). 2 Kleinzeller, A. A., and Kovac, K. L., Nature, 183, 1402 (1959). 3 Cowic, D. B., Roberts, R. B., and Bolton, E. 'T., Science, 118, 379 (1954).

\section{Susceptibility of Mycoplasma (Pleuro- pneumonia-like Organisms) and Bacterial Protoplasts to Lysis by Various Agents}

Tre Mycoplasma organisms (pleuropneumonia-like organisms, PPLO) are limited by a thin and plastic cell envelope ${ }^{1}$. The absence of diaminopimelic acid and hexosamines in Mycoplasma ${ }^{2,3}$ indicates the absence of the 'mucopeptide complex' from their cell envelope. The thickness of the Mycoplasma cell envelope was found to be $\sim 75 \AA .^{1}$, which is similar to that of the cytoplasmic membrane of bacteria ${ }^{4}$. These findings might indicate that the Mycoplasma have no cell wall and are limited only by a membrano resembling the cytoplasmic membrane of bacterial protoplasts. In order to elucidate this point, a comparative study of some of the properties of the Mycoplasma organisms and bacterial protoplasts was carried out.

Mycoplasma laidlawii strain $A$ and Mycoplasma mycoides var. capri were grown in a modified liquid 